\title{
Substantive Equality and Equal Opportunity: A Jurisprudential Appraisal
}

\section{Michel Rosenfeld $\dagger$}

The belief in equality of opportunity ranks aniong the nost deeply entrenclied tenets of American political ideology. ${ }^{1}$ Equality of opportunity lias been recognized in numerous Supreme Court equal protection decisions ${ }^{2}$ and is mandated by significant legislation. ${ }^{3}$ Upon examination, however, the concept of equality of opportunity proves to be elusive and paradoxical. In his recent and thouglitful article, Peter Westen proposed to resolve the mystery of equal opportunity by breaking it down into its constituent elements. ${ }^{4}$ According to Professor Westen, the mystery vanishes once we understand that tlie concept of opportunity denotes a formal relationship rather than a particular state of affairs, ${ }^{5}$ and that "equal" in the context of equal opportunity is purely derivative. ${ }^{6}$ Professor Westen defines an opportunity as an agent's chance to attani a goal in the absence of a specified obstacle or set of obstacles. ${ }^{7}$ "Equal opportunity," then, ineans no more tlian a class of agents liaving the chance to attain the same goal in the absence of the same specified obstacle or set of obstacles. ${ }^{8}$

$\dagger$ Professor of Law, New York Law School. B.A. 1969, M.A. 1971, M. Phil. 1978, Columbia University; J.D. 1974, Northwestern University School of Law.

1. See, e.g., D. RAE, D. YATES, J. Hochschild, J. Morone \& C. Fessler, Equalities 64 (1981) [hereinafter EQUALITIES].

2. See, e.g., Regents of the Univ. of Cal. v. Bakke, 438 U.S. 265, 324 (1978) (Brennan, J., concurring in part and dissenting in part) ("The court today ... affirms the constitutional power of Federal and State Governments to act affirmatively to achieve equal opportunity for all."); see also, Wilkinson, The Supreme Court, The Equal Protection Clause, and The Three Faces of Constitutional Equality, 61 VA. L. REv. 945, 984 (1975) (although endorsed by the Supreme Court, equality of opportunity does not fit neatly within the multi-tiered levels of scrutiny analysis employed by the Court in deciding equal protection cases).

3. See, e.g., Title VII of the Civil Rights Act of 1964, 42 U.S.C. 2000e-2(a)(2), which imposes an obligation to provide equal opportunity in employment; see also Furnco Constr. Corp. v. Waters, 438 U.S. 567, 579 (1978) ("It is clear beyond cavil that the obligation imposed by Title VII is to provide an equal opportunity for each applicant regardless of race ...." (emphasis in original)); Exec. Order No. 11,246, 3 C.F.R. 339, § 101 (1965): "It is the policy of the Government of the United States to provide equal opportunity in Federal employment for all qualified persons."

4. Westen, The Concept of Equal Opportunity, 95 ETHICs 837 (1985).

5. Id. at 842 .

6. Id. at 843 .

7. Id. at 841 .

8. Id. at 844 . 
One of the principal virtues Professor Westen claims for his construct is that it clarifies the inherent vagueness of equal opportunity legislation. ${ }^{9}$ According to Professor Westen, these statutory provisions are deficient because they typically fail to specify obstacles that must be removed in order to acheive their stated goal of equal opportunity. ${ }^{10}$ An additional deficiency stems from the statutes' failure to specify the class that is to be granted equal opportunities. ${ }^{11}$ From Professor Westen's perspective, specification of the relevant class of persons and the particular obstacles to be removed would proinote the very opportunities legislators seek to enhance while removing the vagueness and ambiguity. ${ }^{12}$

Professor Westen is to be commended for pointing out that equality of opportumity does not refer to a monolithic or immutable state of affairs. ${ }^{13}$ Further, he persuasively suggests that there are equal opportunities ratler than a single equal opportunity; ${ }^{14}$ that a distinction must be drawn between the descriptive and prescriptive uses of equal opportunity; ${ }^{15}$ and that equal opportumity is not necessarily desirable. ${ }^{16}$ His analysis, however, is flawed by his narrow conception of opportunity and his erroneous characterization of "equal" as purely derivative. Indeed, in Professor Westen's conception, an opportunity is the equivalent of a negative freedom; that is, it is simply the absence of certain obstacles. ${ }^{17}$ This view is deficient inasmuch as some opportunities require more than mere negative freedoms. For example, an opportunity to pursue a career that requires a graduate degree may well not be within the reach of a person of inodest financial ineans even if no obstacles other than the high cost of a graduate education stand in his or her way.

Furthermore, even if equal opportunity may in some cases be derived fronı negative freedoms, there are other cases in which prescriptive and descriptive conceptions of equality are indispensable in determining which opportunities ought to be pursued. To illustrate this, let us assume that because of its limited resources a society must choose between providing remedial education to victims of past discrimination and subsidizing specialized training for highly educated professionals.

\footnotetext{
9. Id. at 845 .

10. Id.

11. Id. at 846 .

12. Id. at $845-46$.

13. Id. at 849 .

14. Id. at 849-50.

15. Id. at 849 .

16. Id.

17. For a discussion of the distinction between negative and positive freedom, see generally $\mathbf{I}$. BERLIN, Two Conccpts of Liberty, in Four EsSAYs ON LIBERTY 118-72 (1969). According to Berlin, negative political freedom "is simply the area within which a man can act unobstructed by others." Id. at 122. For the meaning given in this Article to "positive freedom," see infra note 25 and accompanying text.
} 
Let us assume further that without the benefit of a remedial education, the discrimination victims will lack any realistic opportunity to compete in the job market, and that without the specialized training, the educated professionals will be unable to help produce a universally desired scarce good in sufficient quantity to satisfy each person's desire equally. Under these circumstances, one cannot rationally decide which one of these two opportumities ought to be pursued absent a normative judgment determining whether equal opportunity in the job market or equal distribution of the scarce good ought to be accorded a higher priority.

This Article has two principal aims. One is to establish that a coherent and comprehensive concept of equal opportunity must rely on a theory of substantive equality. This theory questions the narrow conception of opportunity advanced by Professor Westen. I argue that Professor Westen's conclusion-that "equal" in "equal opportumity" is purely derivative-can only be justified if we accept his imisleading concept of opportunity.

The second principal aim is to examine some of the salient consequences of adopting the predorminant hiberal theory of substantive equality. Viewed in this hight, the concept of equal opportunity is complex and somewhat indeterminate, but nevertheless precise enough to guide the determination of which opportumities ought to be distributed equally and of how that should be accomphished. This analysis will demonstrate that equality of opportunity is not reducible to formal equality of opportunity, as one imight be inclined to conclude from Professor Westen's narrow conception of opportunity. Equality of opportunity may not be limited to the inere removal of specified obstacles. It must also encompass "fair" equality of opportunity; that is, our theory must at times account for and address the prospects for an individual's success. ${ }^{18}$

The final Part of the Article uses a particnlar theory of substantive equahity to demonstrate the inherent weakness of Professor Westen's conclusion that vagueness and ambiguity of statutory provisions niay be overconie by eliminating references to equal opportumity and by specifying relevant obstacles. Equality of opportunity for any given member of a designated class often depends on something besides the removal of the obstacles faced by all members of that class.

I

THE NARROW CONCEPTION: OPPORTUNITY AS NEGATIVE FreEDOM

Professor Westen's concept of opportumity is structured as a formal relationship established by a negative freedon1. As Professor Westen rea-

18. See infra text accompanying notes $34-35$ and $76-82$. 
sons: "'Opportunity' is the word we use to refer to the absence of a specified obstacle or set of obstacles, the absence of which leaves no insurmountable obstacles explicitly in the way of [an agent] X's attaining [a goal] Y."19 Similarly, a negative freedom is a freedom from something; it is valued because it enables its possessor to do something that he or she would otherwise be prevented from doing. Thus, a negative freedom denotes the following formal relationship: A subject $X$ is free from $Z$ in order to be free to do $Y$, where $Z$ is an obstacle which, if present, would prevent $X$ froin doing $Y .^{20}$ Because the narrow conception of opportunity denotes the saine formal relationship as a negative freedom, one can be substituted for the other. For example, a subject enjoys the negative freedoin to worship in public if the government and others who might prevent him from worshiping in public refrain from interfering. Similarly, it may also be said tliat he enjoys an opportunity to worship in public if these same obstacles do not stand in his way.

To the extent that an opportumity is the equivalent of a negative freedoin, "equal" in "equal opportunity" may be purely derivative. To claim that all meinbers of society have the same opportunity to worship in public is the same as saying that these people have an equal opportuinity to worship in public. It is also the equivalent of saying that each person enjoys the sane negative freedoin to worship in public, and that each is equally (negatively) free to worship in public. In the previous statements the terms "equal" and "equality" indicate only that each meinber of the defined subject class possesses the particular opportunity or negative freedoin under consideration. Thus these terms are purely derivative.

Professor Westen also argues that an opportunity is something more than a "inere possibility" but less than a "guarantee" of attaining a coveted goal. ${ }^{21}$ As Professor Westen acknowledges, this is the most "elusive" element in his analysis. ${ }^{22}$ Further examination reveals the inherent limitations of Professor Westen's narrow conception of opportunity.

It is true that an opportunity falls somewhere in the spectrun between a inere possibility and a guarantee. For exainple, there is a mere possibility that in the future I may go to the moon because it is technologically feasible for a person to travel to the moon, and because I possess the negative freedoin to travel wherever I wish if iny government inuposes no restrictions on iny freedom to travel. Notwithstanding this inere possibility, however, it hardly seeins appropriate for ine to characterize this as an opportunity. The reason that $I$ do not have an opportunity to go to

19. Westen, supra note 4, at $840-41$.

20. See I. BERLIN, supra note 17 , at 118 .

21. See Westen, supra note 4 , at 839 .

22. Id. 
the moon is because I do not have access to the means to travel imto outer space, and because the prospects of my gaining access to such means are virtually nil.

On the other hand, where a subject is guaranteed success in achieving his or her goal, it is more appropriately considered an entitlement than an opportunity. Thus, if I am guaranteed that I will get a job for which I have apphed, then for practical purposes I have become entitled to it. It would seem odd, if not misleading, to claim that I have an opportunity to obtain the job im question.

An opportunity is not coextensive with a negative freedom because there are circumstances in which a negative freedom affords no more than a mere possibility that its subject will obtain a desired goal and other circumstances in which it effectively guarantees that a goal inay be achieved. ${ }^{23}$ Nevertheless, the narrow conception of opportunity inay be maintamed by limiting its apphication to opportumities that can ouly occur in the coinpetition for relatively scarce goods. These are goods that are not so scarce that those who compete for them have virtually no prospect of obtaining them, and that are not sufficiently abundant that virtually every competitor can expect to obtam them. By confining opportunities in this manner, a competitor's prospects of success will not be so low as to amount to nothing more than a "mere possibility," or be so high as to become the equivalent of a "guarantee." In short, the narrow conception of opportunity can be defended ouly if it is understood that an opportunity is coextensive with a negative freedom to obtain a moderately scarce good.

II

\section{THE LIMITS OF THE NARROW CONCEPTION OF OPPORTUNITY}

As we have seen, an opportunity's existence depends on a subject's prospects of success in obtaining a coveted good. Moreover, a subject's prospects are dependent upon the means that he or she may employ in competing for a coveted good. ${ }^{24}$ In the competition for a moderately

23. There may be circumstances in which a negative freedom to pursue an activity is, as a practical matter, tantamount to being entitled to it. For example, if all that is necessary to be able to worship in public is that no one interfere with a subject's access to public places of worship, then a legally enforceable negative freedom to worship in public would effectively operate as a guarantee that anyone will be able to worship in public if he or she so wishes.

24. For a description of the relationship between means and prospects in the context of equalities of opportunities, see EQUALITIES, supra note 1, at 65-70. Rae argues that the relatiouship between means and prospects is complex and dependent upon many variables. Nevertheless, he states, "Given strictly uuequal talents, every policy of means-regardiug equal opportunity must violate equality of prospects, and every prospect-regarding equal opportunity must violate equality of means." Id. at 69. 
scarce good, a subject's prospects are not only dependent upon the means at his or her disposal but they are also significantly dependent upon the means of other competitors. For example, if an apple orchard located a few miles fronı a community is opened for public harvesting once a year, and everyone in the coinmunity is able to walk to the orchard, each member of the coinmunity has an opportunity to obtain apples. However, if we assume that there are fewer apples than the number needed to satisfy every inember of the community, and that sonie but not all members of the community have access to automobiles, sonie people may lack a real opportunity of obtaining apples froin the orchard. If half the coininunity had access to automobiles and half did not, and if the orchard contained only enough apples to satisfy one half of the demand for apples, the pedestrians' prospects of obtaining apples would be reduced to no more than a "inere possibility." By the same token, the inotorists' prospects would increase to the point of near certainty.

Once it is acknowledged that an individual's opportunity to obtain a good depends on the prospects and hence the means of success of other competitors for the sanie good, it becomes apparent that the narrow conception of opportunity is too limited. Indeed, creating an opportunity inay require the acquisition of goods that furnish the means to engage in a ineaningful competition for a coveted good. Alternatively, ensuring an opportunity inay also require that certain coinpetitors be deprived of soine of the means at their disposal. Finally, providing an opportunity may require a coinbination of granting ineans to some and depriving others of certain ineans. In terms of the apple orchard exaniple, pedestrians inay be provided access to a inotor vehicle, or a sufficient number of their conpetitors inay be deprived the use of their vehicle. In either case, the pedestrians' prospects of obtaining apples would be enhanced beyond a "mere possibility." Moreover, opportunities to obtain apples could be achieved by a combination of granting and denying transportation to the orchard so that all coinpetitors would have nore than a mere possibility but less than a virtual assurance of success. Thus, having an opportunity is not always the equivalent of enjoying a negative freedom. In some cases, competition for certain scarce goods may need to be channeled or regnlated $\mathrm{m}$ ways that are not reducible to the mere removal of specified obstacles. In other cases, having an opportunity requires establishing a positive freedom.

Unlike a negative freedoin to be left alone, a positive freedom involves an affirmative course of assistance designed to put a person in a position ineaningfully to pursue a particular good. ${ }^{25}$ A positive freedom

25. Unlike negative freedom, whose object is noninterference, the aim of positive freedom is self-realization. I. BERLIN, supra note 17, at lvii. Positive freedom "depends on the absence of impediments over and above simple coercion (understood as direct political and social interference 
may be construed in the same way as a negative freedom, that is, as requiring the removal of an obstacle standing between the subject and his or her pursuit of the particular goal. For example, to enjoy the positive freedom to compete for college admission, an applicant must liave graduated from high school. The freedoin, or opportunity, to conpete for a place as a college student can thus be construed as the removal of the obstacle of not graduating from higli school. Consistent with this analysis, proponents of the narrow conception of opportunity may claim that the specification of opportunities is broad enough to encompass both positive and negative freedoms. Indeed, there is no valid logical reason why positive freedoms may not be recast in terms of the removal of obstacles. Nevertheless, the kind of "obstacle" associated with positive freedoms is altogether different from the kind typically associated with negative freedoms. $^{26}$

When considered from the perspective of state-implemented opportunities, the inaccuracy of equating negative and positive freedoms is evident. A legal or political freedom-whetler it is labeled "positive" or "negative"-imvolves not only a subject who is free to pursue a coveted goal, but also an agent who may impose or remove "obstacles" whicl, if present, would negate the subject's freedom. Assuining the government to be the agent, in order for the subject to enjoy a particular freedom, either the government would have to refram from imposing an obstacle (and prevent others froin imposing a similar obstacle), or it would have to remove an existing obstacle by allocating goods that would provide the subject with the ineans to enjoy that freedom.

From the government's standpoint, lowever, maintaining a negative freedom is not the equivalent of creating and supporting a positive freedom. In the case of a negative freedon1, the government must priniarily refrain from interfering (and insure tliat otliers do not interfere) with

with what any individual might wish to do, plus direct invasion of one individual by other individuals)." C.B. MacPherson, Democratic TheORY: EsSAys IN RETRIEVAL 105 (1973). Accordingly, positive freedom is likely to require that the government provide the individual with certain basic necessities. See F. Oppenheim, Polttical Concepts: A Reconstruction 94-95 (1981); see also D.D. RAPHAEL, JUSTICE AND LIBERTY 52-53 (1980) (positive liberty requires the development of individual capacities through aid and training provided by others). Thus, any freedom that depends on some affirmative course of government action rather than on mere noninterference may be referred to as a "positive freedom." Rosenfeld, The Jurisprudence of Fairness: Freedom Through Regulation in the Marketplace of Ideas, 44 FORDHAM L. REV. 877, 880 (1976).

26. See I. BERLIN, supra note 17, at 131-32:

The freedom which consists in being one's own master, and the freedom which consists in not being prevented from choosing as I do by other men, may, on the face of it, seem concepts at no great logical distance from each other-no more than negative and positive ways of saying much the same thing. Yet the 'positive' and 'negative' notions of freedom historically developed in divergent directions not always by logically reputable steps, until, in the end, they came into direct conflict with each other. 
relevant activities of that freedom's subject class. In the case of a positive freedom, however, the government must also allocate goods to the relevant subjects so that they may enjoy the freedom in question. ${ }^{27}$ Moreover, to the extent that a positive freedom to obtain a good depends on the acquisition of another good, a government's decision to provide that freedom must also assume the obligation to allocate the goods upon which the freedom depends. For example, if a government decides to provide the positive freedom to pursue a college education, and if graduation from high school is a prerequisite for admission to college, the government must guarantee a high school education. Furthermore, correlative to the government's assumed obligation is the right of each citizen to obtam a high school education. In short, an individual's positive freedom to pursue a goal, may depend on her having a positive right to a particular good, the possession of which is a prerequisite for the very possibility of obtaining that goal.

A positive freedom, like a negative freedom, is an opportunity if it allows a subject to enjoy prospects for obtaining the object of his or her freedom that are greater than a "mere possibility" but smaller than a "virtual certainty." Unlike an opportumity that is based upon a negative freedom, however, an opportumity that depends upon a positive freedom is likely to require not only the removal of obstacles but also the distribution of particular goods and even the grant of certam rights. Under these circumstances it is, at best, misleading to view a positive freedom that ensures more than a mere possibility of success exclusively in terms of the removal of specified obstacles.

In addition an even more serious objection to the narrow conception arises because an individual's opportumity to attain a goal generally depends upon others' prospects of attaining the same goal. That is, the connection between some individuals' opportunities and others' prospects generates cases in which an opportunity simply cannot be the equivalent of "the absence of a specified obstacle." 28 This connection was illustrated by the apple orchard example discussed above. ${ }^{29}$ It is important to note, however, that the different means of altering competitors' relative prospects of success are likely to be greater in number in actual cases than they are in the apple orchard hypothetical. Indeed, in the hypothetical all the members of the relevant class are assumed to possess identical means in all areas other than transportation. In real life, even in a simple situation like the apple orchard example, there is a

27. See Rosenfeld, supra note 25 , at $880-81$; see also F. OPPENHEIM, supra note 25 , at $94-95$ (government may make the basic necessities of life available to enable individuals to act as free persons); D.D. RAPHAEL, supra note 25, at 52-53 (positive liberty involves action by others in the form of aid and training in the development of capacities).

28. Westen, supra note 4 , at 840 .

29. Supra at p. 1692. 
greater disparity of means ranging over a broad spectrum of human activity. It is fair to conclude, then, that the greater the number of variables affecting competitors' relative prospects for particular goods, the less sense there is to viewing opportunities im terms of the mere removal of specified obstacles. ${ }^{30}$

Consistent with this analysis, Professor Westen's definition of opportunity may be replaced with the following: A subject $X$ has an opportunity to obtain a goal $Y$, where $Y$ is moderately scarce so that not all who wish to obtain $Y$ can succeed in their aim, and where $X$ 's prospects of competing and obtaining $Y$ fall somewhere between a mere possibility and a virtual certainty. Moreover, a subject's opportunity to obtain a given goal not only depends on his available means but also on those that are available to the other subjects who wish to attain the same goal.

\section{III}

\section{The Role of EQUALITY}

Because an opportunity depends in part on the means and prospects of others, reducing equality of opportunity to the removal of a given obstacle for a class of subjects will lead to equahity of opporturity among the members of that class only in the unlikely event they have identical individual circumstances and each possesses exactly the same means and confronts the very same obstacles. Professor Westen's claim that "equal" in "equal opportunity" is purely derivative requires the validity of two propositions. The first proposition-that opportunities are the equivalent of negative freedoms-has been shown to be misleading. The second-that equality of opportunity consists exclusively of removing specified obstacles for a particular class of individuals-is either the product of pure coincidence, or the result of one of several conceptions of substantive equality.

This last point may be illustrated by reference to the conditions necessary to justify Professor Westen's thesis. Opportunities are reducible to negative freedoms in a society in which legal impediments are the only obstacles that hinder imdividuals in their efforts to reach goals: For example, in a society with no great disparities in individual wealth, repealing a law that prohibits mmorities from acquiring real estate would create an opportunity for them to do so. Within the parameters of Pro-

30. Of course, it is possible from a purely logical point of view to characterize a situation in which an opportunity's existence depends on a number of different variables in terms of the "removal of specified obstacles." Thus, not only the implementation of positive freedoms, but also the reallocation of goods, the removal of goods, or a combination of the two must be reinterpreted as removing obstacles. Such reinterpretation is pointless. In many cases the complexity and indeterminacy of identifying the particular obstacles that are implicated defeats any purpose that might otherwise justify the recharacterization of various states of affairs in terms of obstacles to be removed. 
fessor Westen's thesis, ${ }^{31}$ the repeal of all opportunity-inhibiting laws is sufficient to establish equality of opportunity in a society in which all obstacles to opportunities are legal impediments.

"Equal opportunity," however, niay be used in one of two distinct senses. It may be used in the sense of "prospect-regarding" equality. In this sense, "[t]wo persons, $j$ and $k$, have equal opportunities for $X$ if each has the sanie probability of attaining X."32 Equal opportunity may also be used in the sense of "means-regarding" equahity. In this sense, "[t]wo persons, $j$ and $k$, have equal opportunities for $X$ if each has the sanie mstruments for attaining X." ${ }^{\prime 33}$ Under Professor Westen's rubric, the repeal of all offending laws ought to create equal prospects or equal means for all. Achieving an equality of prospects or an equality of ineans simply by the repeal of certain laws, however, would be highly coincidental. Indeed, achieving equal prospects fron the repeal of certain laws is unlikely unless there is a lottery-like process of distribution. Sinilarly, in the case of equal ineans, it is counterintuitive to think that the inere repeal of certain laws would leave the same instrunients in the hands of each and every meniber of society.

The claim that equality of opportunity niay be acheived nierely through the removal of obstacles may be justified only by understanding the normative framework underlying this claim, and thus by abandoning the proposition that "equal" in "equal opportunity" is purely derivative. To facilitate this understanding, we inust first recognize that there are at least two different approaches to the problem of means-regarding equality of opportunity. To illustrate, assume that the relevant ineans to obtain a certain scarce job include: natural talent, inaterial tools of the trade, and absence of legal obstacles that prevent one from obtaining the position. It is consistent with means-regarding equality of opportunity to clain that it deinands only the removal of legal obstacles for all, regardless of inequalities in natural talents or in the possession of niaterial tools. It is equally consistent with ineans-regarding equality of opportunity, however, to clain that it requires not only the removal of legal obstacles but also the distribution of relevant material tools. Proponents of the former position, that equality of opportunity requires the elinination of legal obstacles, are recognized as advocates of "formal equality of opportunity." 34 Those who insist that equahity of opportunity requires the additional elimination of all relevant differences directly attributable to

31. See supra note 8 and accompanying text.

32. See Equalities, supra note 1 , at 65.

33. Id. at 66 .

34. Formal equality of opportunity has been defined as follows: " $\mathrm{X}$ and $\mathrm{Y}$ have equal opportunity in regard to [A] so long as neither faces a legal or quasi-legal barrier [to achieving $A$ that] the other does not face." R. FULLINWIDER, THE REVERSE Discrimination ConTROVERSY 101 (1980). 
inequalities in social conditions are advocates of "fair equality of opportunity." 35

The strongest justification for the claim that means-regarding equality of opportunity is possible even though only some of the relevant means are equally distributed is provided by formal means-regarding equality of opportunity. This categorization, lowever, is substantive rather than derivative. This is evidenced by the sharp distinction that formal means-regarding equality of opportunity draws between the absence of legal obstacles that might preclude attaining a certain goal and the presence of other means that are clearly relevant to the pursuit of the goal. ${ }^{36}$ Specifically, formal equality of opportumity tolerates the significant inequalities that are caused by differences in social conditions and natural talents. Tolerance of inequality is legitimated by the broader normative framework underlying formal equality of opporturity-a framework that values the minimal state ${ }^{37}$ and conceives of individual autonomy in terms of the rights of persons to be left alone. ${ }^{38}$ This worldview is that typically associated witl hibertarian theory from Locke to Nozick. ${ }^{39}$

35. Cf. J. RAwLS, A THEORY OF JUSTICE 73 (1971) (requirement that careers selecting talent should be supplemented by the principle of fair equality of opportunity, under which "those with similar abilities and skills should have similar life chances.... irrespective of the income class into which they are born").

36. Compare R. FULLINwIDER, supra note 34 (arguing that formal equality of opportunity addresses only the legal barriers encountered by job seekers; if all legal barriers were removed, job opportunities would be based simply on the individual's talent) with J. RAwLS, supra note 35 (fair equality of opportunity recoguizes the problems of social and economic inequalities which must be corrected in order to achieve equality of opportunity).

37. The libertarian paradigm posits the individual as essentially self-sufficient, but not beyond the reach of other individuals, who could, if they chose, interfere with his or her pursuit of self-interest.... The principal function of libertarian society ... is to guarantee the separation and isolation of each individual from the rest of society. The principal means to achieve this purpose is the protection of natural rights, which are, primarily, rights to exclude others from one's own sphere of legitimate interests.

Rosenfeld, Contract and Justice: The Relation Between Classical Contract Law and Social Contract Theory, 70 Iowa L. Rev. 769, 786-87 (1985). See generally J. LoCKE, The SeCOND TrEatise of GOVERNMENT (J. Gough 4th ed. 1976) and R. NOZICK; ANARCHY, STATE AND UTOPIA (1974). Locke's work is the classic foundation for the libertarian position. Its chief contemporary advocate is Nozick. P. PetTrt, Judging Justice 75-76 (1980).

38. The role of the minimal state in classical liberal theory is generally limited to "the functions of protecting all its citizens against violence, theft, and fraud, and to the enforcement of contracts." R. Nozick, supra note 37 , at 26 . Nozick, who is the chief contemporary exponent of the libertarian position, maintains, "The minimal state is the most extensive state that can be justified." Id. at 149.

Contrast the minimal state with the welfare state's active role in redistributing wealth in order to satisfy the basic needs of every citizen. Cf. M. WALzer, SPHEREs of Justice 74 (1983) ("The arguments for a minimal state have never recommended themselves to any siguificant portion of mankind. ... The political community grows by invasion as previously excluded groups, one after another ... demand their share of security and welfare.").

39. The libertarian position is supported and justified by the broader normative framework that values the primacy of the individual over social goals. Individualism as a theory seeks an 
If the government's principal function is to safeguard an individual's right to be left alone, it is hardly surprising that opportunities are viewed as negative freedoms. Similarly, it follows that equality of opportunity is conceived as a means to eliminate those government-supported obstacles that are likely to interfere with the exercise of individual autonomy. In the last analysis, the thesis that equality of opportunity consists of the removal of obstacles can be justified only if equahty of opportunity is regarded as strictly formal. Reducing equality of opportunity to formal equality of opportunity may be justified, but only within the normative construct advanced by hibertarian theory. To the extent that Professor Westen's construct of equality of opportunity may be justified, this justification does not confirm his claim that equahty is derivative. On the contrary, it indicates that his conception can only be free of arbitrariness if it is viewed within a theory of substantive equality.

\section{IV}

\section{From Equality of OpPoRTunity to SUBSTANTIVE EQUALITY}

Determining what constitutes equality of opportunity is coniplex and problematic. This is due $\mathrm{m}$ part to the fact that equality of opportunity is determined in relation to two inequalities: inequality of initial circumstances and inequahty of result. The relation of equality of opportunity to inequahty of result is quite obvious. As Rae noted, "Opportunities of power, right, and acquisition are to be equal; power, right, and acquisition themselves are not." 40 For example, if a group of applicants is said to have an equal opportunity to obtain a single job it usually means that they have an equal chance or that they are entitled to equal consideration in the selection of the person. In other words, all applicants will be considered equally but only one will acquire the job.

equilibrium between individual rights and individual welfare. In turn, different paradigms of individualism suggest various ways of reaching this desired equilibrium. See Rosenfeld, supra note 37 , at 776-804.

In the Lockean version of the libertarian paradigm the equilibrium between individual rights and individual welfare is maintained by the enforcement of the natural right to property. Such a natural right guarantees a broad measure of individual autonomy, but it is far from clear that it also assures each individual the minimum he or she requires in order to enjoy the fruits of autonomy. Nevertheless, this limitation is not fatal to Locke's libertarian paradigm because he assumes that, in the absence of interference from others, the individual is self-sufficient.

Id. at 788. (footnotes ommitted). Consistent with this, formal equality of opportunity is justified because it removes obstacles that prevent individuals from reaching self-sufficiency. In other words, formal equality of opportunity is sufficient to further the aims of libertarian individualism precisely because every individual is already assumed to possess the requisite means to obtain self-sufficiency. The only thing that the individual needs from society, therefore, is to be left alone to pursue these goods.

40. EQUALITIES, supra note 1 , at 64 . 
On the other hand, the relation between equality of opportunity and inequality of initial circumstances is nore difficult to grasp. Indeed, while inequality of result necessarily is linked to equality of opportunity in a nontrivial sense, this is not the case with inequality of initial circumstances. ${ }^{41}$ Inequality of initial circunıstances exists because conpetitors for scarce goods usually come from different backgrounds and have different experiences, talents, and capacities. Equahty of opportunity may be thought of as a legitimating factor in the transition between inequality of imitial circunistances and inequality of result. ${ }^{42}$ As Rae points out, equality of opportunity is usually constructed in terms of the provision of equal means-that is, equal rules and equal tools-so that unequal talents are revealed and unequal prospects of success will result. ${ }^{43}$ For instance, competitors in a footrace are all provided with the sanie set of rules. It is likely, then, that the athlete with the greatest speed will win the race. Moreover, to the extent that the race is fair because all the racers are identically equipped and all are subjected to the sanie rules, these equal nieans legitimate the unequal prospects of success and the eventual unequal outcoine of the race. ${ }^{44}$

Under one view, inequahity of imitial circumstances would determine the ultimate allocation of unequal results. Thus, if the initial circuinstances created widely divergent talents, and if society imposed no constraints on free competition for scarce positions, jobs would tend to be filled by those who possessed the most talent. Furthermore, if this result was justified, equality of opportunity would require simply that there be no interference with the natural progression fron 1 a particular inequality of initial circumstances to the particular inequahty of result to which it leads. On the other hand, equahity of opportunity nuay ensure that niequalities of result are a function of sone, but not all, of the inequahities of initial circumstances. For example, if the initial circumstances were characterized by inequalities in natural talents and education, equality of

41. It is possible to imagine that each member of a class who is about to compete for the same position possesses exactly the same means; assume they all come from identical backgrounds, have identical upbringings and education, and possess identical talents, capacities and motivations. Under these circumstances, equality of initial circumstances coupled with formal equality of opportunity leads to both equality of means and equality of prospects among all members of the class. If one assumes the existence of perfect competition, such competition will not produce the desired result-the determination of the most qualified applicant for the position. Instead, the competition demonstrates that all applicants are equally qualified. Therefore, under these circumstances, equality of opportunity requires that the position be awarded on some basis other than competition, for example, by a lottery system.

42. Cf. Equalities, supra note 1, at 66 (equal means can be used to demonstrate unequal talents and capacities and to legitimate unequal prospects of success).

43. EQUALITIES, supra note 1 , at 66 .

44. See id. 
opportunity might equalize the levels of education so that inequalities of result would be the exclusive function of inequalities in natural talents.

Determining which inequalities of initial circuinstances ought to be neutralized and which ought to be allowed full expression is both complex and controversial. Disagreenients about the nature and scope of equahity of opportunity reflect the difficulties of making such determinations. These problems require that principled distinctions, consistent with the primciple of equal opportunity, be inade between those inequalities in the initial circumstances that ought to be neutralized and those that ought to influence inequalities of result.

To better understand substantive equality, it is necessary to distinguish-as Professor Westen does-between "equality" in a descriptive sense and "equality" in a prescriptive sense. ${ }^{45}$ As Professor Westen observes, descriptive equality notes what is, prescriptive equality suggests what ought to be.$^{46}$ In the descriptive sense, equality is a concept relating likes and unalikes. ${ }^{47}$ Equality requires that equals be treated equally, and as a corollary, that unequals be treated differently. ${ }^{48}$ Descriptive equality, however, does not specify who are to be considered as equals, or in what respect they nust be alike in order to be entitled to equal treatment. Assuming that no two individuals are conipletely alike, equal treatment of persons who are alike in some respect will involve unequal treatınent of persons who are alike in sonie other respect. ${ }^{49}$ For example, if need rather than merit was the factor relative to which individuals were entitled to equal treatnient, all those having the same needs would receive an equal allocation of goods. To the extent that persons having equal inerit niay not possess the same needs they would be treated unequally. Because of its relational nature, equality is bound to create some inequality. "The question" as Rae argues "is not 'Whether equality?' but 'Which equality?." 50 As a descriptive concept, equahity cannot supply an answer to that question. As a prescriptive concept, equality can be niade sufficiently determinate in content to guide the determination of which equalities ought to be pursued.

There is no general agreenient as to the proper bounds of prescriptive equality. Even so, since the eighteenth century Western society has

45. See Westen, supra note 4, at $842-43$.

46. Id.

47. Cf. EQUALrTIES, supra note 1 , at 26 ("equality is a purely relational concept" (emphasis in original)).

48. Rosenfeld, Affirmative Action, Justice and Equalities: A Philosophical and Constitutional Appraisal, 46 Oно ST. L.J. 845, 850 \& n.30 (1986).

49. "[B]ecause of the antagonisms between one equality and another, there must always be some inequalities. For any society with structural complexity, there must be choices among equalities, hence equalities left out." EQUALITIES, supra note 1, at 144 (emphasis in original).

50. EQUalities, supra note 1 , at 19 (emphasis in original). 
valued the proposition that individuals are morally equal. ${ }^{51}$ This proposition, which I have termed the "postulate of equality," provides the concept of equahity with substantive content. ${ }^{52}$ The postulate of equality does not identify particular traits with respect to which individuals are equal..$^{53}$ Rather, it suggests that, at a minimum, all individuals are moral actors entitled to equal autonomy and respect, capable of making moral choices $^{54}$ and of rationally pursuing their life-plans. ${ }^{55}$ The postulate of equality simply proposes broad parameters withm which equality of opportunity has normative justification; it justifies those equalities and inequalities that, in a given social context, are compatible with equal autonomy and respect for all.

The primciple of equal autonomy and respect requires, as Michael Walzer suggests, that we define criteria for the distribution of social goods. "Equality," he argues, "is a coniplex relation of persons, niediated by the goals we make, share, and divide among ourselves; it is not an identity of possessions. It requires then, a diversity of distributive criteria that mirrors the diversity of social goods." 56 These criteria divide the universe of social and pohtical relationships into distinct spheres of justice, ${ }^{57}$ which n1ay be divided generally into the spheres of assimilation and the spheres of differentiation.

A sphere of assimilation refers to that category of social goods that should be distributed without regard to a particular individual trait. ${ }^{58} \mathrm{~A}$ sphere of differentiation refers to that category of social goods that

51. See A. GutmanN, Liberal EQUality 18 (1980) ("The belief in human equality . . . is an idea that ... is basic to the modern doctrine of individualism, equal respect for the human dignity of all people being essential to the realization of individual autonomy, the protection of privacy and the opportunity for self-development" (footnote omitted)); see also Feher and Heller, Forms of Equality in JusTICE 149, 152 (E. Kamenka \& A. Erh Soon Tay eds. 1980) (since the eighteenth century, almost all social systems regard equality as a positive value).

52. The postulate of equality has been a centerpiece of liberal philosophy. See Equalrries, supra note 1, at 96; R. Nozick, supra note 37, at 232-38; J. RAWLS, supra note 35, at 504-12; Dworkin, Liberalism, in Public and PRIVate MoRality 123-40 (S. Hampshire ed. 1978). Moreover the postulate of equality has also been the cornerstone of the American form of constitutional government as evidenced by the famous dictum of the Declaration of Independence"all men are created equal." See Tussman \& tenBroek, The Equal Protection of the Laws, 37 CALIF. L. REv. 341 (1949).

53. See Williams, The Idea of Equality, in JUSTICE AND EQUALITY 116-37 (H. Bedeau ed. 1971) (noting that persons are viewed as moral equals because they share a common humanity, even though persons are not equal in wealth, skill, or intelligence).

54. See A. GutmanN, supra note 51, at 35.

55. See J. RAWLS, supra note 35, at 92-93: “[A] person's good is determined by what is for him the most rational long-term plan of lifc.... To put it briefly, the good is the satisfaction of rational desire."

56. M. WALZER, supra note 38 , at 18 .

57. See id. at 10.

58. Wasserstrom, Racism, Sexism and Preferential Treatment: An Approach to the Topics, 24 UCLA L. REV. 581 (1977). 
should be distributed by taking that particular trait into account. ${ }^{59}$ For instance, to the extent that the principle of equal autonomy and respect makes it morally impermissible to award jobs on the basis of religion, the job market is a sphere of assimilation with respect to differences in religious affiliation. Conversely, to the extent that the principle of equal autonomy and respect makes it morally impermissible to interfere with the freedom to worship, religious worship is a sphere of differentiation with respect to differences in religious affiliation. In its broadest terms, then, equalities inust be constructed so that those who are different are not regarded as inferiors, and conforming identities are not imposed upon them. ${ }^{60}$

In its historical context, the postulate of equality developed as a moral weapon against the privileges of status and birth that were fundamental to feudal authority. ${ }^{61}$ At a minimum, the postulate of equality rejects status or birth as a basis for differential treatment. Thus, under a model of substantive equality of opportunity, inequalities of status and birth ouglit to be neutralized so that the results of social, political, and economic interaction are not merely a function of differences in birth and status.

In cases in which coveted scarce goods are awarded on the basis of birth or status, other differences, sucli as fitness or talent, are substantially neutralized. Neutralization of differences in birtl and status allows differences in fitness and talent to replace the disparities in privilege as the key factor in allocating coveted scarce goods; this in turn is likely to produce increased opportunities. Under the achievement-based distribution, assuming that differences in fitness and talents are not extreme, most individuals enjoy more than a mere possibility of obtaining those scarce goods.

Neutralizing differences in status and birth promotes equality of opportumity in two ways. First, equality of opportunity as a negative freedom is created by eliminating obstacles based on inequalities of status and birth for those who would compete for certain scarce goods but for such inequalities. Second, equality of opportunity for a much broader class of persons is created by competition based on differences in capacities, talents, and the degree of effort expended-provided that capabilities and talents are susceptible to development through practical experience

59. M. WALZER, supra note 38 , at 18 .

60. There has been a tendency to associate difference with inferiority. Similarly, equality has been associated with identity. See T. TODOROV, LA CONQUETE DE L'AMERIQUE: LA QUESTION DE L'AUTRE 152 (1982). Ideally, equality does not force persons to conform for the sake of identity and it respects all genuine differences without exploitation of them. See id. at 253; Rosenfeld, supra note 48 , at 866 .

61. See S. Benn \& R. Peters, The Principles of Political Thought 132 (1965). 
and learning ${ }^{62}$ and that the range of differences in capacities and talents is not so great as to provide nothing more tlian a "mere possibility" of success. If these conditions are inet, all the coinpetitors in a systein free of status bias will be likely to possess means-regarding equality of opportunity.

Equality of opportunity in the sense of equality of means is fragile and susceptible. If capacities and talents vary widely, providing equal means will nevertheless result in unequal prospects. When the differences between prospects extend beyond a certain range, some people are bound to be left without any opportunity. Furthermore, unequal utilization of equal means inay lead to future inequality of means that is subsequently reinforced and deepened by that very mequality. This process n1ay develop a split between those who are virtually assured of obtaining the goods they desire, and others who are almost certain to fail in their efforts to acquire scarce goods.

Because the historical struggle against privilege provides the postulate of equahity with a minimun of content, equality of opportunity requires at least the neutralization of inequalities of status and birtli in the allocation of scarce goods. ${ }^{63}$ If the subjects of equality are then left with the same ineans to obtain scarce goods, there is a full equality of opportunity. If neutralization of differences in status and birth does not create equal neans, then only a partial equality of opportumity is established. In either case, lowever, the domain of equality of opportunity reinains narrowly confined.

Alternatively, the normative aims of the postulate of equality may be satisfied if goods could be distributed so that each individual were able to realize fully his life-plan. ${ }^{64}$ Satisfying individuals' life-plans requires an unequal distribution of goods because each individual's life-plan varies as to the number and kind of social goods required. Even though this distribution would be marginally unequal, a global equality would result as ineasured by the satisfaction of each individual's life-plan. ${ }^{65}$ Under the circumstances of complete abundance, equality of opportunity would be unnecessary because every desire would be satisfied.

In contrast, the presence of scarcity makes the distribution of goods

62. If this was not the case an aristocracy based on status would merely give way to an aristocracy based on innate talent.

63. S. BENN \& R. PETERS, supra note 61, at 132.

64. Rosenfeld, supra note 48 , at 853 .

65. "Marginal equality is defined with respect to (often small) changes from the status quo, with the changes being equal in magnitude for all. Global equality is defined with respect to holdings above zero, with their amounts or end states being equal." EQUALITIES, supra note 1, at 51 (emphasis in original). Accordingly, achieving global equality from inequality of initial circumstances requires marginal inequalities in the allocation. There are cases, therefore, in which global equality depends upon the unequal distribution of means to the intended beneficiaries of the global equality. 
more difficult. We must ask whether goods should be distributed in equal lots or in proportion to the satisfaction they are likely to create. Equahity through equal lot distribution, which eliminates altogether any need for equahity of opportunity may be appealing, but from the perspective of the postulate of equahty, it is deficient. Chief among these shortcomings is its mability to account for differences between individuals or to distribute mdivisible goods in equal lots. Failure to appreciate individual differences reduces equality to identity, while the inability to distribute indivisible goods is unnecessarily wasteful.

To overcome the first of these shortconings, one might distribute goods in proportion to their marginal utility to the recipients. This approach might provide the best means of achieving the postulate of equality under conditions of scarcity, if it were practical to neasure the degree of individuals' satisfaction produced by the distribution and if goods were infinitely divisible. In these circumstances, there would be no rooln for equality of opportunity because everyone would be given a lot proportionate to his or her wants and needs.

Because of the limitations on communicating and understanding subjective states and desires, however, the value of a particular good to the fulfillment of a given individual's life-plan may be unascertainable. ${ }^{66}$ As a consequence, a distribution predicated on the satisfaction of the same proportion of each mdividual's wants and needs-that is, on subject-regarding equahity - may be altogether impossible to iniplement. Thus, both lot-regarding equality of result and subject-regarding equality of result ${ }^{67}$ obviate the need for equality of opportunity under conditions of scarcity, yet each is seriously deficient if not impossible to implenient.

The failings of lot-regarding and subject-regarding equality of result as distributive inechanisms lead proponents of the postulate of equality to equahity of opportunity. This is best shown in cases in which the requirements of subject-regarding equality coincide with those of lotregarding equahty. For exanıple, consider a group of persons trapped inside a building that is on fire and assume that each of those trapped cannot escape froin the burning building without assistance from outside. $^{68}$ Each person, regardless of his or her particular life-plan, has an equal need for the saine good-that is, the services of an outside rescuer. If the rescuer is a firefighter and if each firefighter is able to save one person, then the postulate of equality, lot-regarding equality, and

66. See Rosenfeld, supra note 37, at 778; $c f$. Kennedy, Form and Substance in Private Law Adjudication, 89 HARV. L. REV. 1685, 1769 (1976) (individualism adheres to the view that individual values are inherently arbitrary and subjective).

67. Subject-regarding equality is an equality of result in the sense that the distribution of unequal lots places each recipient in a position to satisfy an equal fraction of the sum of his or her wants and needs.

68. This example is also considered in Rosenfeld, supra note 48, at 854-55. 
subject-regarding equality all could be satisfied by sending as inany firefighters to the rescue as there are persons trapped inside the building.

A moral dilemma arises when there is a shortage of firefighterswhen, for exainple, there are one hundred persons trapped inside the building and only fifty firefighters. Either everyone inside the building is treated equally and they all perish, or half are saved and those left behind are treated unequally. Because there is no justification for differentiating among those trapped-that is, all are in equal need of rescue and none is less deserving than any other-unequal treatment would be a prima facie violation of the postulate of equality, even if hives may be saved.

Dworkin's distinction between the right to equal treatment and the right to be treated as an equal helps to resolve this dilemma. ${ }^{69}$ According to Dworkin, there is a fundamental right to be treated as an equal and receive the same concern and respect accorded others. In contrast, the right to equal treatment is purely derivative. ${ }^{70}$ Dworkin's distinction corresponds to the postulate of equality's rejection of an inflexible requirement of equal treatınent that would reduce equality to identity.

Even though each person trapped inside the building is morally entitled to equality of result, each would probably be willing to give up a claim to equal treatment and certam death for a fifty percent chance of survival. The problem would be to ensure that those who ultimately will not be rescued are nevertheless treated as equals. Equality of opportunity provides the means of treating all as equals even though only half will be saved. ${ }^{71}$ In this example, equality of opportunity refers to prospect-regarding equality consisting of a procedure, such as a lottery, that would afford each person the same probability of being rescued. Such a lottery would not violate any individual's right to be treated as an equal because selection would be coinpletely randoin, and thus would not treat anyone as an inferior because he or slie is different. In this sense, a lottery should be contrasted with alternative means of determining who shall survive, such as race or sex. Determining survival on the basis of racial or sexual differences where such differences are irrelevant violates the riglit of those who must ultimately die to be treated as an equal.

This example presents an unusual coincidence between lot-regarding and subject-regarding equahty. Nevertheless, the general proposition set forth-that equality of opportunity is mandated by the postulate of equality whenever equality of result would be required if it were not

69. See R. DWorkin, TAKING Rights Seriously 227 (1977).

70. Id.

71. See N. Rescher, Distributive Justice 94 (1966) ("“[R]esort to the concept of 'equality of opportunity' is a faute de mieux procedure, a counsel of despair, as it were. It represents a means for achieving an equalization of opportunities (and risks) in cases in which a direct allocation of shares to claims is infeasible.") 
impossible to achieve because of a scarcity of goods-holds true in all other cases as well. ${ }^{72}$ In such cases, the difficulty is in determining, absent scarcity, whether equality of result is required and what equality of result should be provided.

Although scarcity may arguably justify the shift from equality of result to prospect-regarding equality of opportunity, it does not necessarily justify the shift to means-regarding equality of opportunity. As previously discussed, the possession of equal means may not enable some people to attam more than a mere possibility of acquiring a desired good. In these cases, an unsatisfactory equality of result may be rejected and prospect-regarding favored over means-regarding equality of opportumity. Beyond these cases, a fundamental question about the legitimacy of means-regarding equality of opportumity as an alternative to equality of result under conditions of scarcity is raised.

A fully developed answer to this latter question is beyond the scope of this Article. In general terms, however, prospect-regardimg equality of opportumity is appropriate for goods whose distribution is independent of their production. Conversely, means-regarding equality of opportunity is more appropriate for goods whose distribution ought to be directly linked to their production. ${ }^{73}$ Returning to the example of the people trapped inside the burning buildimg, receiving the firefighters' aid clearly does not bear any relation to the "production" of firefighters' services (that is, setting up a fire department, training the firefighters, etc.). In contrast, if a group of high school students is provided with equal means to develop the skills necessary to obtain scarce college admissions, admissions ought to be allocated to those who made the best use of the means rather than to the winners of a lottery, particularly if skills development depends more on perseverance than on native talent. Moreover, the justification for this is that the distribution of college admissions to the most qualified candidates is likely to enhance the production of goods that are dependent on their producers completing a college education. Thus, means-regarding equality of opportumity ought to be preferred to prospect-regardimg equahity of opportunity if it affords real opportunity to all and results in a greater number or greater quality of goods capable of satisfying a greater proportion of existing demand without denying anyone's right to be treated as an equal. ${ }^{74}$

On the other liand, except in the extraordinary case in which means-

72. For a more extensive discussion of the relationship between equality of opportunity and equality of result, see Rosenfeld, supra note 48, at 855-57.

73. Cf. Williams, supra note 53, at 127-28 (arguing that essential goods such as medical services ought to be distributed on the basis of need rather than merit).

74. This would also seem to conform to individualism's broader aim of achieving an equilibrium between individual rights and individual welfare. See supra note 39. 
regarding equality of opportunity leads to equal prospects for all, equality of nieans allows certain inequalities of initial circunistances, or inequalities resulting from the allocation of equal means, to result in unequal distribution. Hence, allowing a free course to a particular inequality of initial circunistances, or inequality resulting from the allocation of equal means, can only be justified whenever the unequal result and the means-regarding equality of opportunity to which it is linked are theniselves justified.

Furthermore, as previously discussed, equality of means is frequently ephenieral because unequal exploitation of the saine means tends eventually to produce inequality of means. In addition, full equality of means is often difficult to achieve and, paradoxically, may not always advance the ainis of the postulate of equality. For exaniple, providing all children with fully equal means to compete for scarce goods may require removing some of them fron their families because an economically deprived family, or one that embraces unusual values, may not provide its children with valued skills supplied to others. In these circumstances, pursuit of a coniplete means-regarding equality of opportunity violates the family menibers' right of autononiy and reduces equality to a conforming identity. ${ }^{75}$ To the extent that full equality of opportunity cannot be achieved without violating sonie person's right to be treated as an equal, full equality of opportunity should yield to an equalization (falling short of full equality) of opportunities that preserves autononiy-enhancing differences.

Althougl the preceding analysis does not specify which particular equalities and inequalities of opportunity are required by the postulate of equality, ${ }^{76}$ it demonstrates that true equality of opportunity camiot always be reduced to a formal equality of opportunity. It is true that in some cases in which equality of result would be appropriate but for the existence of scarcity, nieans-regarding equality of opportunity might be preferable to prospect-regarding equality of opportunity because the former would lead to increased production of desirable goods. In this context, formal means-regarding equality of opportunity may satisfy the exigencies of the postulate of equality, absent wide variations in social, econonic, and educational advantages. ${ }^{77}$ However, adherence to the postulate of equality suggests circumstances in wlich fair ratlier than formal equality of opportunity is justified. ${ }^{78}$ Where variations in social, economic, and educational advantages are so pronounced that the iniple-

75. See, e.g., J. Fishkin, Justice, EQual Opportunity, and the Family 50-51, 106-07, $145-46$ (1983).

76. The specification of particular equalities of opportunity requires reference to concrete social, political, and historical facts.

77. See supra note 41 .

78. Contractarians, too, have argued that fair equality of opportunity is better suited than 
mentation of formal equality of opportunity would leave a substantial number of people without any real opportunity of success, the postulate of equality requires the pursuit of fair equality of opportunity, provided only that it is superior to prospect-regarding equality of opportunity.

The principal function of fair equahty of opportunity is to conpensate for discrepancies in social, economic, and educational advantages in order to improve the prospects of those who would otherwise enjoy no more than a mere possibility of success in the competition for desirable scarce goods. ${ }^{79}$ Moreover, fair equality of opportunity niay tend to neutralize all disparities in social conditions found in the relevant set of initial circumstances, rendering eventual inequalities of result the exclusive product of differences in natural talent. ${ }^{80}$ In the latter case, fair equality of opportumity justifies marginal inequalities that lead to global equality ${ }^{81}$ with respect to all relevant means except natural talents. Thus, the pursuit of fair equality of opportunity may justify the distribution of certain goods to part of the subject class and the taking of other goods froni other members of the class. Moreover, there may be circunistances in which global equahty justifies the temporary imposition of affirinative action plans based on preferential treatment. ${ }^{82}$ In sun1, equality of opportunity may require unequal treatment as a prerequisite to the global equalization of means-regarding opportunities; any attenipt to reduce equality of opportunity to the mere removal of the same specified obstacles for all menibers of the subject class therefore fails to satisfy the requirements imposed by the postulate of equality.

\section{$\mathrm{V}$ \\ STATUTORY INTERPRETATION AND EQUAL OPPORTUNITY}

Professor Westen's suggestion to replace references to equal opportunity found in statutes with prescriptions to remove specified obstacles ${ }^{83}$ should be rejected under the foregoing analysis. Professor Westen's proposal might reduce vagueness and ambiguity, but in a siguificant nuniber of cases it would defeat the purpose of establishing or preserving equality of opportunity.

formal equality of opportunity to promote the aims of justice. See A. GOLDMAN, JUSTICE AND REVERSE DISCRIMINATION 175-76 (1979); see also supra note 39.

79. Cf. A. GolDMAN, supra note 78 , at 179 ("attack on social disadvantages is demanded by the moral priority of equality").

80. Id. at 179-81 (although elimination of socially created disadvantages is justified, attempts to counter inequalities in natural talents would violate the integrity and autonomy of the person).

81. See supra note 65.

82. See A. Goldman, supra note 78 , at $191-92$ (advocating preferential treatment as a means to achieve fair equality of opportunity for the chronically poor because chronic disincentives to seek out opportunities have rendered members of this group less likely to benefit from programs where opportunities depend upon motivation).

83. Westen, supra note 4 , at $845-46$. 
To illustrate how the elimination of references to equal opportunity would frustrate the purpose of an equal opportunity statute, refer to the statute cited by Professor Westen in support of his thesis. ${ }^{84}$ The pertinent portion of the statute may be divided into two parts: part one prescribes equal opportunity in eniploynient and part two proscribes discrimination against any person seeking eniployment from an employer subject to the statute on the basis of race, color, religion, national origin, or sex. ${ }^{85}$ Professor Westen argues that part one is superfluous "because part [two] contains everything one needs to know." ${ }^{86}$ Specifically, he interprets the statute as being no inore than a proscription of racial, ethnic, rehigious, or sexual barriers to that employment covered by the statute. ${ }^{87}$ Consistent with this interpretation, Professor Westen asserts that the statute does not proscribe other forms of discrimination, such as discrimination based on sexual preference. ${ }^{88}$

This interpretation is flawed in several respects. First, although prohibition of certain forms of enıployınent discrimination may tend to create equahity in some circumstances, this would certainly not be true in all cases. For example, where a society practiced systematic, long-term discrimination in education and einployinent against ineinbers of a racial minority, a statute prohibiting continued racial discrimination in hiring may be insufficient to produce equality of opportunity. Given pronounced disparities in the distribution of social, economic, and educational advantages, a race-neutral eniployment-selection statute inay be insufficient to ensure nore than a inere possibility of obtaining scarce eniployment by menibers of the group hitherto discriminated against. It is easy to conceive of cases in which a racial minority would lack any real opportunity to obtain scarce einployinent absent race-conscious laws that discriminate in its favor. ${ }^{89}$ Hence, eliminating race-based hiring obstacles may be desirable under many circumstances, but it is by no means coextensive with the pursuit of equality of opportunity.

Second, Professor Westen is wrong in contending that part one of the statute is superfluous. It is deinonstrably not superfluous if its refer-

84. See id. at 845. The statute is the Public Telecommunications Act, 47 U.S.C. § 398(b)(1) (1982), which provides in relevant part: "Equal opportunity in employment shall be afforded to all persons by the Public Broadcasting Service ... and no person shall be subjected to discrimination in employment ... on the grounds of race, color, religion, national origin, or sex."

85. 47 U.S.C. $\$ 398(b)(1)$ is typical of those provisions prescribing equal opportunity in employment.

86. Westen, supra note 4 , at 845 .

87. Id. at 846.

88. Id.

89. See Regents of the Univ. of Cal. v. Bakke, 438 U.S. 265, 362-63 (1978) (Brennan, J., concurring in part and dissenting in part) (medical school's preferential admissions program constitutionally justified, as equality of opportunity for all cannot be achieved with neutral means due to past discrimination). 
ence to "equality of opportunity" is understood to mean "fair equality of opportunity" rather tlian "formal equality of opportunity." Indeed, if part one of the statute is interpreted as prescribing fair equality of opportunity,--meaning that inequalities among applicants due to differences in social conditions ought to be neutralized in the employment selection process covered by the statute-then it is the primcipal provision of the statute. In that case, part two could be interpreted as imposing certain limitations on the means einployed to carry out part one's general prescription. Accordingly, although the social equahizations mandated by part one might have been achieved througl race-conscious or sex-conscious means, part two precludes the use of such nieans. ${ }^{90}$

If part one of the statute is not superfluous, Professor Westen's claim that the statute does not proscribe discrimination on the basis of sexual preference is unsupported. The legitimacy of discrimination on the basis of sexual preference could not be resolved under the postulate of equality and fair equality of opportunity by a reading of the statute on its face. Absent more precise statutory language, resolution of this question requires a normative evaluation consistent witl the postulate of equality's prescriptions. This evaluation would determine whether taking sexual preference into account in the allocation of employment-assuming that it is not a job related characteristic-would cast certain nieinbers of society as inferiors, or whetlier it would reduce equahty to conforming identity, thus violating the postulate of equahity's preservation of individual autonomy. ${ }^{91}$

It may be advisable to require more specificity in the drafting of equal opportunity statutes, but not the kind of specificity advocated by Professor Westen, and not for the reasons he advances. It would be useful to specify whetlier a particular statute intends to promote prospectregarding or means-regarding equality of opportunity or whetlier it seeks to establish fair or merely formal equality of opportunity. It night also be lielpful if statutes specified which ineans are to be equal or equalized for the relevant class and which differences in means sliall be considered legitimate.

Still, there is much to be said for not making equal opportunity statutes more specific. Equality of opportunity is not a static concept, at least for those wlio einbrace the postulate of equality. At any given time, which of the niany possible meanings of equal opportunity should prevail will depend on the social, political, and historical conditions confronted

90. Cf. United Steelworkers of Am. v. Weber, 443 U.S. 193 (1979) (discussing whether the failure of Title VII of Civil Right Act of 1964 to "require" preferential treatment of disadvantaged groups implicitly permitted or prohibited such affirmative action).

91. See supra note 60 and accompanying text. 
by those who seek it.92 Consistent with the postulate of equality's prescriptions, prospect-regarding equality of opportunity would be preferable to means-regarding equality of opportunity in sonie circumstances. In other circumstances formal equality of opportunity would be sufficient, and in still other circuinstances a commitment to fair equality of opportunity is called for. For this reason, legislators should prescribe the establishment of equal opportunities and leave it to those charged with the adininistration and interpretation of equal opportunity statutes to specify a statute's requirements in a given set of circuinstances.

\section{CONCLUSION}

Conibining a narrow conception of opportunity with a purely derivative view of equality inverts the proper relationship between equality and opportunity in "equality of opportunity." Opportunity encoinpasses inore than negative freedoms: equality can play the dominant role in "equality of opportunity," determining both what counts as an opportunity and which opportunities ought to be distributed equally.

Equahity of opportunity has a central place in the normative universe shaped by the postulate of equahty. Establishing equal opportunities is desirable wherever equal results would be justified but for scarcity of the coveted goods sought to be allocated. Equatity of opportunity would not be justified, however, wlierever equal results could be achieved under conditions of abundance, or where its pursuit would mhibit the realization of the greatest possible individual autononiy consistent with equal autonomy for all.

"Equal opportumity" enconipasses inany different kinds of equalities, including equalities of prospects and equalities of ineans. Achieving equality of opportunities sornetines requires only formal equalities; at other tinies it demands commitnient to the establislinient of fair equalities. On some occasions, equality of opportunity is satisfied by the removal of the same specified obstacles for all the inenibers of the relevant subject class. Elsewhere, lowever, it is satisfied only by tolerating certain nrarginal inequalities, suclı as distribution of different goods to different inembers of a relevant subject class.

In the last analysis, the concept of equal opportunities is coinplex, nuultifaceted, and always indeterminate. Nevertlieless, it is a useful and flexible tool in the service of the postulate of equality. To rid all statutes of references to equal opportunity therefore would achieve siniplicity and precision at the cost of severely depleting the available nieans of aclieving the postulate of equality. The concept of equal opportunity inay be difficult to pinpoint because it enconipasses nrany different equal-

92. See Rosenfeld, supra note 48 , at 858 . 
ities and inequalities; however, a flexible concept is preferable to one that would restrict the achievement of the goal of equality. 